\title{
New records of brown algae (Phaeophyta) from the Azores
}

\author{
M. I. Parente' ${ }^{\text {, R. L. Fletcher }}{ }^{2}$ \& A. I. Neto ${ }^{1 . *}$ \\ ${ }^{1}$ Secção de Biologia Marinha. Departamento de Biologia. Universidade dos Açores, \\ Rua da Mãe de Deus, 9500 Ponta Delgada. Azores, Portugal \\ Tel: +351-296653044.Fax:+351-296653155.E-mail: aneto@notes.uac.pt \\ ${ }^{2}$ University of Portsmouth, Institute of Marine Sciences, Ferry Road, Eastney, Portsmouth, \\ Hampshire PO4 9LY, U.K. \\ Fax: +351-296653155. E-mail: ancto(notes.uac.pt "Author for correspondence)
}

Key rords: Phaeophyta, Atlantic Ocean, the Azores, new records

\begin{abstract}
The following five species of microscopic tuft-forming/encrusting brown algae (Phaeophyta) are newly recorded for the Island of São Miguel (Azores): Nemoderma tingitana Schousboe ex Bornet, Pseudolithoderma roscoffense Loiseaux (Lithodermataceae), Hecatonema terminalis (Kützing) Kylin (Punctariaceae), Compsonema saxicolum (Kuckuck) Kuckuck, and Microspongium gelatinosum Reinke (Scytosiphonaceae). The species are described, and information is presented on their ecology and distribution around the island.
\end{abstract}

\section{Introduction}

Relatively little attention has been given to studies of the smaller, tuft-forming and crustose brown algae (Phaeophyta) of the Azores. Neto (1994) listed 70 species of Phaeophyta from the Azores, including six tufted and one crustose species, the cosmopolitan Ralfsia verrucosa, first listed for the islands of Pico and Faial by Tittley \& Neto (1994). To provide better knowledge of the marine brown algal flora of the Azores, with particular respect to the smaller microscopic species, field work was undertaken on the island of São Miguel. Particular attention was given to searching for crustose species of brown algae. As a result of this survey, five new records of small brown algae are given, along with preliminary data on their distribution. seasonality and ecology.

\section{Materials and methods}

From May 1998 to May 1999, seven interticlal sites on the island of São Miguel (Fig. 1) were sampled at monthly intervals. Study sites were surveyed, and collections of stones, shells, chiseled portions of bedrock, and trapped plastic and wood substrata with obvious brown spots, crusts or small tufts were made. In the laboratory, algae were identified using a combination of stereoscopic and compound microscopes. Where appropriate, measurements were made of cells and other structures using a calibrated micrometer eye piece. After staining in either fast green or crystal violet, permanent slides were made of all algae collected. A reference collection was made, and each specimen was given an herbarium code number and stored in $5 \%$ buffered formaldehyde seawater solution. A representative collection of colour slides was made using an OLYMPUS-PM 10-35 AD-1 microphotographic system. Camera lucida drawings of all diagnosing features were made using a Leitz Laborlux microscope with a drawing tube. All collections are numbered and deposited at the University of Azores.

\section{Results}

The following five new records of small brown algae were recorded during the survey and are decribed below: Psendolithoderma roscoffense and Nemodema tingitana (Lithodermataceae); Compsonema saxicolum and Microspongium gelatinosum (Scytosiphonaceae); Hecatonema terminalis (Punctariaceae) 


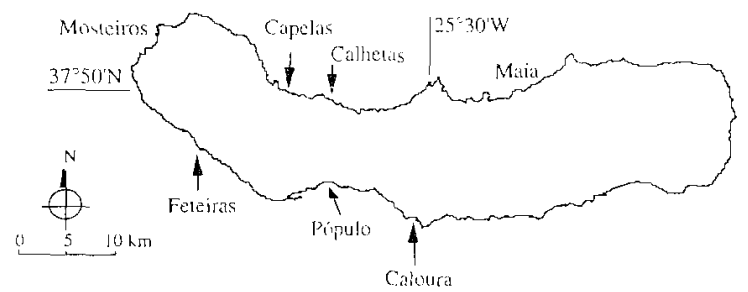

Figure 1. Location of the seven study sites on the island of Sino Miguel (Azores).
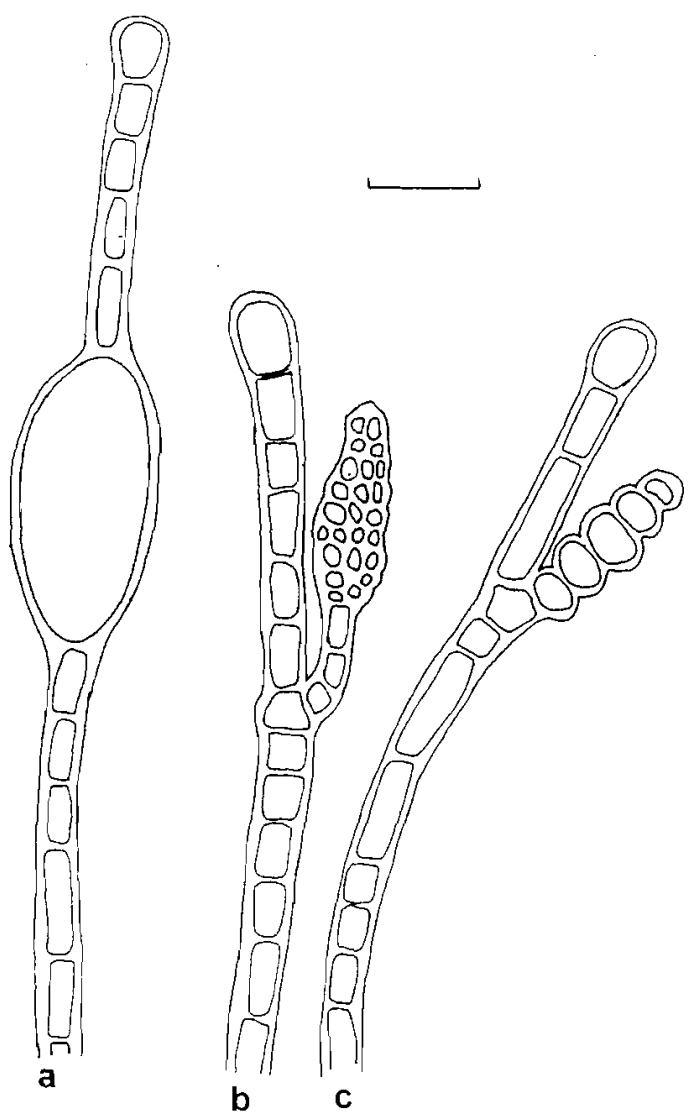

Figure 2. Nenoderma ringituna: (a) sporangia arising from intercalary cells: (b) male and (c) lemale gannetangia arising baterally. $B a{ }^{\circ}=25 \mu \mathrm{m}$

(see Fletcher, 1987 for taxonomic grouping). Under each species, the herbarium code numbers are listed.

\section{Descriptions of plants}

Lithodermataceae

Nemodemina fingitana Schousboe ex Bornet (Fig. 2) SMG-98-470: SMG-98-713: SMG-98-1043a: SMG98-1352: SMG-98-1394: SMG-98-1527: SMG-981597: SMG-99-230: SMG-99-452: SMG-99-792.
Epilithic. more rarely epizoic, forming thin, smooth. slightly spongy, yellow crusts, often confluent and irregularly spreading to one square metre, and closely adherent and firmly attached to the substratum. usually without obvious rhizoids. In squash preparations, plants reveal a discoid base of which all cells give rise to erect, monosiphonous unbranched filaments up to 46 cells $(1006 \mu \mathrm{m})$ in length, easily separable under light pressure. Central cells of erect filaments commonly rectangular, measuring 8 $21 \times 8-29 \mu \mathrm{m}$; upper cells more quadrate, elongate or slightly pyriform, measuring $11-18 \times 10-26 \mu \mathrm{m}$ (Fig. 2a). Cells light coloured with several scattered discoid plastids with several pyrenoids. Hairs abundant, grouped and emerging from depressions. In the older crusts. the lower cells contain few or no plastids and appear slightly colourless. Both unilocular sporangia and gametangia were observed. Unilocular sporangia $(17-30 \times 40-67 \mu \mathrm{m})$ develop singly from intercalary cells in the middle to upper parts of the erect filaments and are ovate (Fig. 2a). Male and female gametangia, found on the same plant, are borne laterally at about the same level and also in the upper part of the filaments (Fig. 2b). They form small, elongate clusters of compartments, female gametangia distinctly larger $(25-55 \times 13-20 \mu \mathrm{m})$ than male $(40-45 \times 13-20 \mu \mathrm{m})$.

Plants, observed throughout the year at all the sites except Mosteiros, covered large stones, bedrock and other hard substrata. in the mid to low-tide region of exposed shores.

Pseudolithoderma roscoffense Loiseaux (Fig. 3) SMG-98-573; SMG-98-616; SMG-98-752; SMG-981080; SMG-98-1524; SMG-98-1620: SMG-98-1623; SMG-99-41; SMG-99-446; SMG-99-760; SMG-99802.

Epilithic. forming thin to moderately thick crusts, light brown to black. Adhering firmly to the substratum, plants are irregular and confluent, $5 \mathrm{~cm}$ or more in extent. Thallus comprising a discoid base, giving rise 10 erect, strongly united monosiphonous filaments up to 22 cells (195 $\mu \mathrm{m}$ ) in length (Fig. 3a), enclosed by a thick cuticle. Cells of the erect filaments measure 8-26 $\times 8-18 \mu \mathrm{m}$ and each contains 3-6 or more discoid plastids without obvious pyrenoids. In surface view. apical cells are polygonal. measuring 7-17 $\mu \mathrm{m}$ in diameter (Fig. 3b) and contain several. peripherally placed. discoid plastids: hairs not observed. The rarely observed plurilocular sporangia are terminally positioned in slightly raised mucilaginous 

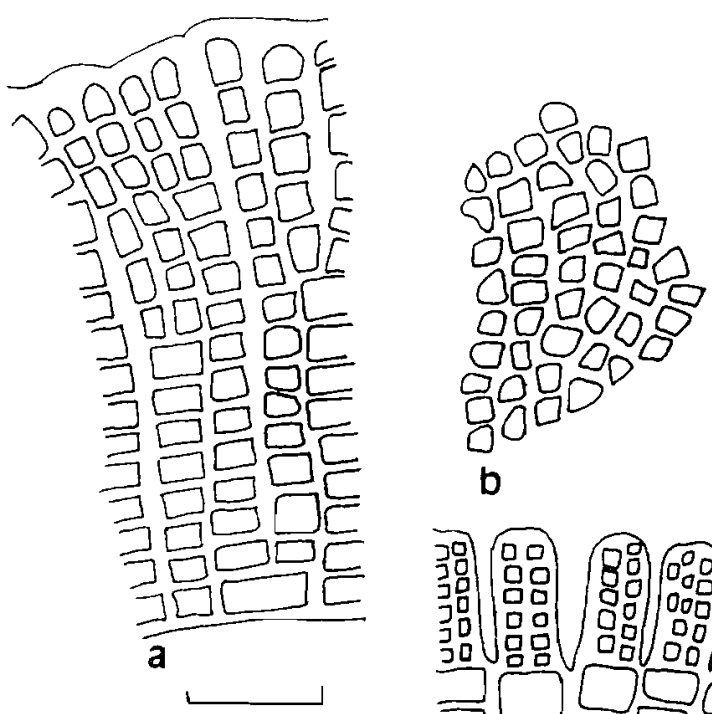

b

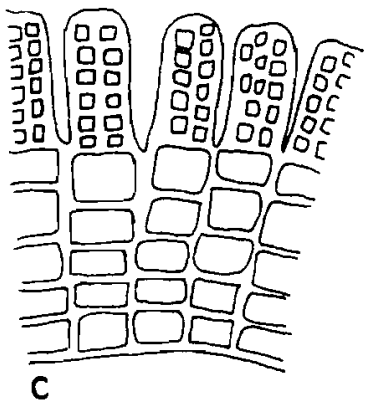

Figure 3. Pseudolithoderma roscoffense: (a) squash preparation of vegetative crust; (b) surtace view; (c) squash preparation of fertile crust with terminal plutilocular sporangia. $\mathrm{Bar}=50 \mu \mathrm{m}$

sori (Fig. 3c). They are biseriate, rarely multiseriate, and are without accompanying paraphyses. Usually, they are covered with a thick cuticle. In vertical section, they appear clavate to slightly pyriform, up to 4-6 compartments high and measure 26-52 × 10-23 $\mu \mathrm{m}$. Unilocular sporangia unknown.

Plants common throughout the year at all localities except Mosteiros and Calhetas, occurring on rocks and stones at low-tide level, often in pools.

\section{Scytosiphonaceae}

Compsonema saxicolum (Kuckuck) Kuckuck (Fig. 4) SMG-98-1 133: SMG-98-1396; SMG-98-1460; SMG98-1461; SMG-98-1463; SMG-98-1464; SMG-981523; SMG-98-1525: SMG-98-1621: SMG-99-40.

Epilithic, tuft-forming, light yellow-brown and spreading to approximately $1-2 \mathrm{~mm}$ in diameter. Tufts comprise a basal layer of branched, outwardly spreading and loosely associated filaments, from which erect filaments arise (Fig. 4a). Cells of the basal layer mainly rectangular, sometimes quadrate measuring 10-16 × 16-30 $\mu \mathrm{m}$, and frequently biseriate Erect filaments linear, up to 44 cells $(492-\mu \mathrm{m})$ long, monosiphonous, unbranched, loosely associated in a

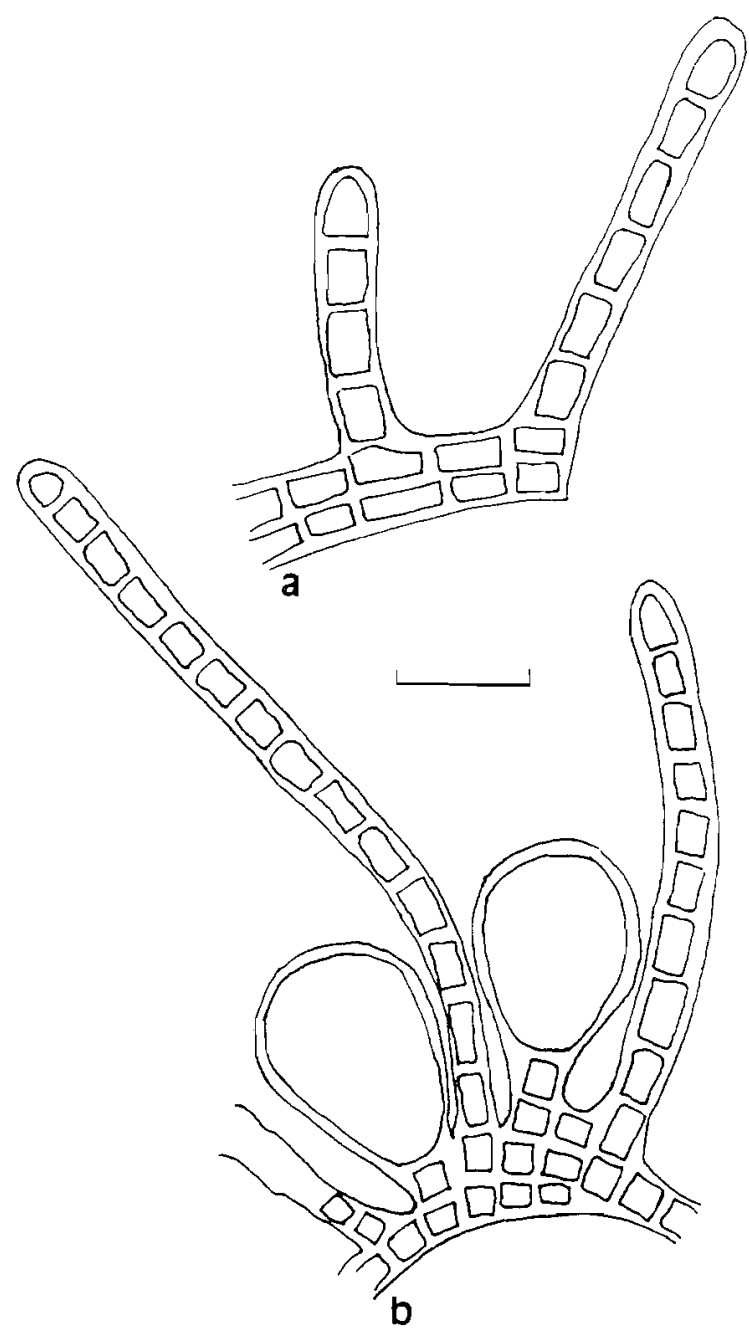

Figure t. Squash preparation of Compsonema saxicolum: (a) vegetative thalli showing erect filaments arising from a distromatic base: (b) fertike thalli showing unilocular sporangia. Bar $=50 \mu \mathrm{m}$.

gelatinous matrix and easily separable under pressure, comprising cells mainly quadrate $(8 \times 13 \mu \mathrm{m})$, sometimes rectangular $(10-13 \times 16-26 \mathrm{~km})$. Cells with a single, plate-like plastid with a conspicuous pyrenoid. Longitudinal divisions sometimes present in the central region of some filaments (Fig. 4b). Hairs common, arising from the basal layer or from terminal cells of the erect filaments. Unilocular sporangia common, pyriform or elongate pyriform, sessile or stalked on basal layer (Fig. 4b), or in some cases, terminal or lateral on erect filaments. Plurilocular sporangia unknown.

Plants uncommon and only recorded at Maia, Caloura and Feteiras; occurring throughout the year on rocks at low-tide level or in pools. 


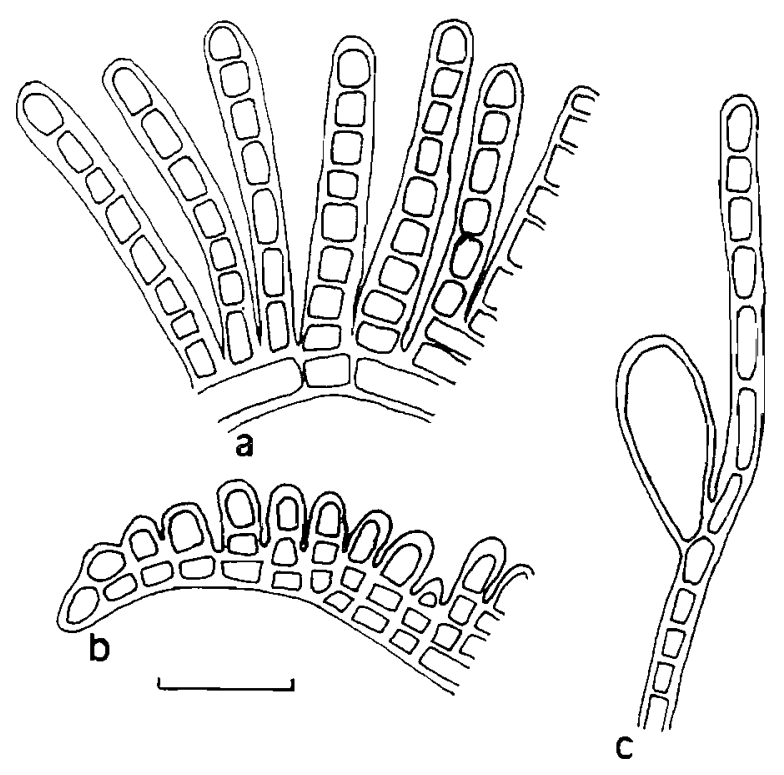

Figure 5. Squash preparation of Microspongium gelatinosum: (a) vegetative thalli showing loosely adjoined erect filaments; (b) crust edge showing marginal apical cell: (c) a fertile thalli showing unilocular sporangia arising at base of paraphyses. Bar $=50 \mu \mathrm{m}$.

Microspongium gelatinosum Reinke (Fig. 5) SMG98-573b; SMG-98-617; SMG-98-620; SMG-98-754; SMG-98-811; SMG-98-829; SMG-98-880; SMG-98947; SMG-98-1043a; SMG-98-1249.

Epilithic, crustose to slightly pulvinate, spongy in texture, dark-brown to black, circular or more commonly irregularly spreading over several centimeters, firmly attached to the substratum, usually without obvious rhizoids. Crusts with a monostromatic base, giving rise to erect, usually unbranched filaments up to 12 cells $(140 \mu \mathrm{m})$ long, coherent but easily separable under pressure (Figs 5a, b). Basal cells, commonly rectangular, measuring $13-30 \times 10-13 \mu \mathrm{m}$, central cells of erect filaments also rectangular but slightly smaller, measuring 10-23 × 8-16 $\mu \mathrm{m}$; upper cells either quadrate, elongate or slightly pyriform, measuring 10-44 $\times 8-16 \mu \mathrm{m}$. Cells with a single, parjetal, plate-like plastid, located in the upper cell region. with one pyrenoid. Unilocular sporangia, in extensive, spongy sori on crust surface, elongate-pyriform or elongate-cylindrical, measuring 60-133 × 18-42 $\mu \mathrm{m}$. commonly sessile (Fig. 5c). Linear paraphyses up to 10 cells. Plurilocular sporangia not observed.

Plants common at all sites except Calhetas and Mosteiros, on rocks and in pools at low-tide level: usually absent during the winter.

Punctariaceate

Hecaronema terminalis (Kützing) Kylin (Fig. 6)

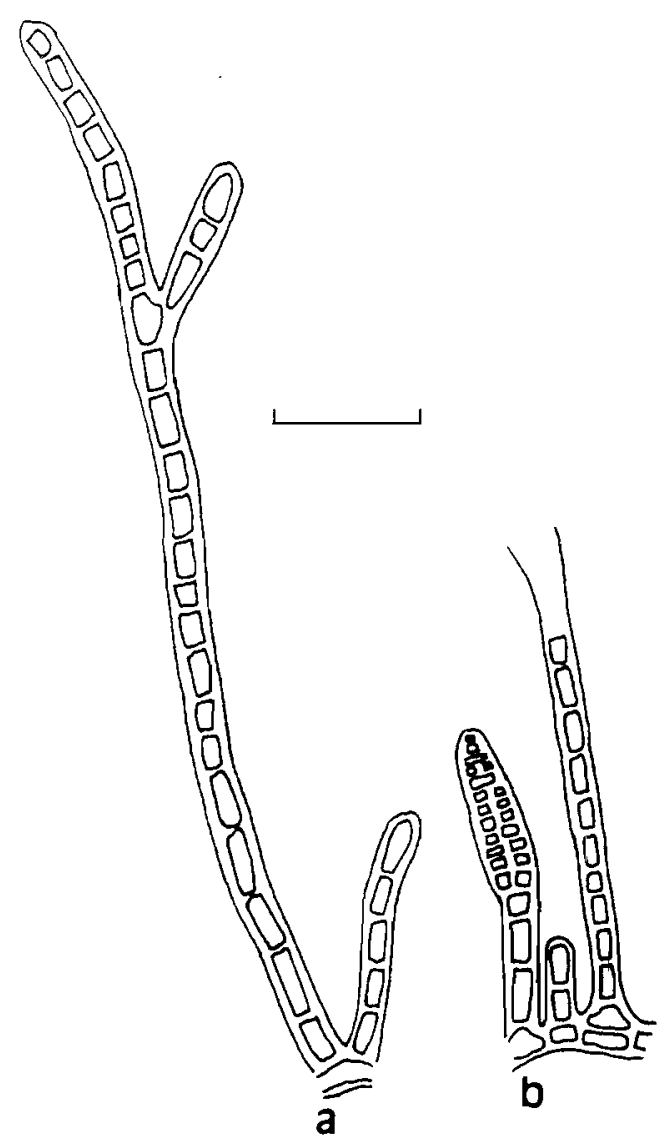

Figare 6. Squash preparation of Hecatonema terminalis: (a) erect filaments arising from basal layer; (b) fertile thalli showing erect filaments arising from a monostromatic/distromatic base. with plurilocular sporangia. Bar $=50 \mu \mathrm{m}$.

SMG-98-370; SMG-98-521; SMG-98-572; SMG98-751; SMG-98-809; SMG-98-810; SMG-98-1622; SMG-99-186; SMG-99-334; SMG-99-615.

Epilithic, forming small, microscopic, light-brown tufts, discrete or more commonly confluent, spreading to approximately $2-4 \mathrm{~cm}$ in diameter. In squash preparations, plants reveal a pseudodiscoid base, comprising cells of variable shape, measuring $7-13 \times$ $16-23 \mu \mathrm{m}$. Basal cells giving rise to erect, unbranched filaments, up to 40 cells (963 $\mu \mathrm{m}$ long), linear and loosely associated in tufts (Fig. 6a). Cells of filaments are mainly recrangular, measuring $10-13 \times$ 17-27 $\mu \mathrm{m}$, occasionally with longitudinal divisions, each containing $1-3$ plate-like plastids. with several pyrenoids; hairs common, arising from the basal layer or terminal on erect filaments. Plurilocular sporangia common, arising from the basal layer on stalks or terminal on short erect filaments (Fig. 6b). ovatelanceolate, biseriate or more commonly multiseriate. 
$20 \times 60 \mu \mathrm{m}$, up to 29 loculi long. Unilocular sporangia unknown.

Plants common at all sites except Calhetas, occurring throughout the year on stones in pools or exposed at low-tide level.

\section{Discussion}

The five new records increase the marine brown algal flora of the Azores to 75 species. Many more collections made on the island of São Miguel await examination and it is likely that the total number of brown algae present will considerably exceed this as more have been recorded on the mainland coast. For example, Ardré (1970) recorded 98 species for Portuguese coasts. Order Ectocarpales is unrepresentative in the list of Azorean species yet is recorded for the mainland coast. It is likely that more collections of large, well known 'host' algae such as Sargassum spp. and Cystoseira spp. will increase considerably the species list. None of the new records is likely to represent recent additions to the flora of the Azores, but have been overlooked until now because of their small size and /or encrusting habit. It is perhaps only surprising that Nemoderma tingitana has not been reported previously, in view of its abundance and the extent of spread of the yellow crusts observed in some localities.

The present paper has extended the distribution of these small algae in the North Atlantic. The Azores now represent the southern limit of distribution for Pseudolithoderma roscoffense, Compsonema saxicolum and Microspongium gelatinosum, and the northern limit for Nemoderna tingitana. Note, however, that Pseudolithoderma roscoffense, only reported previously for northern France (Loiseaux, 1968) and the British Isles (Fletcher, 1987; Fletcher \& Maggs, 1985), may well be conspecific with Lithoderma adriaticum (Fletcher, 1987; Guiry, 1997) which has been reported widely in the Mediterranean Sea. The presence of these species in the Azores confirms the reports of the Azorian flora representing a mixture of cold and warm water species (Neto, 1997).

The discovery of both Compsonema saxicolum and Microspongiun gelatinosum was particularly interesting as both algae have been reported as phases in the life histories of members of the order Scytisphonales (Fletcher, 1987) which is well represented by four species (Colpomenia sinuosa, Hydroclathrus clathratus, Scytosiphon lomentaria and Endartchne binghamiae) in the Azores (Neto, 1994). Culture studies are presently underway to establish any possible life- history connections between these new records and the erect Scytosiphonales. and will be the subject of a later communication. Also interesting was the first report of Hecatonema terminalis in the Azores, although an unidentified Hecatonema sp. was reported by Neto (1994) in her checklist. Material described as Ectocarpus terminalis for the Canary islands by Børgesen (1926) differs from the present material by being more luxuriant in its growth, with erect filaments and plurilocular sporangia reaching much greater dimensions. It is possible that Hecatonema terminalis is conspecific with Hecatonema maculans (Collins) Sauvageau in which case the former would have priority (Wynne, 1998).

\section{Acknowledgments}

We thank the following members of the Universidade dos Açores: Sandra Monteiro for technical assistance in the field and for help with the culture work, Rui Sousa for his help in the field and Marisa Toste for helping with the drawings. We also thank the anonymous referees whose comments improved the manuscript.

\section{References}

Ardré, F., 1970. Contribution à l'étude des algues marines du Portugal. I - La Flore. Portugaliae Acta Biológica. (B) 10: $137-555$.

Børgesen, F. 1926. Marine algae from the Canary Islands especially from Tenerife and Gran Canaria. II Phaeophyceae. K. danske Vidensk. Selsk. Sur. (Biol.) $6(2): 1-112$.

Fletcher, R. L., 1987. Seaweeds of the British Isles. Vol. 3. Fucophyceae (Plaeophyceae) Part I. British Museum (Natural History). London: ix $+359 \mathrm{pp}$.

Fleccher, R. L. \& C. A. Maggs. 1985. Two crustose marine brown algae new to Ireland. It. Nat. J. 21: 523-526.

Guiry, M. D.. 1997. Benthic red, brown and green algae. In Howson, C. M. \& B. E. Picton (eds). The Species Directory of the Marine Fauma and Flora of the British Isles and Surrounding Areas. Ulster. Museum and the Marilie Conservation Society: 341-367.

Loiseaux, S., 1968. Recherches sur les cycles de développement dcs Myrionématacées (Phéophycécs). III Tribu des Ralfsiées. IV Conclusions generales. Rev. gén. Bot. 75: 295-318.

Neto, A. I., 1994. Checklist of the benthic marine macroalgae of the Azores, Arquipélago. Life Mall Sci.. 12A: 15-34.

Neto, A. I., 1997. Sulles on algal communities of São Miguel. Azores. Tese de Doutoramento. Universidade dos Açores. Ponta Delgada: $x+309 \mathrm{pp}$

Tittley. I. \& A. I. Neto. 1994. Benthic marine algae (seaweeds) recorded from Faial and Pico. Arquipélago, Life Mar: Sci. I2A $1-13$.

Wynne. M.. 1998. A checklist of benthic marine algae of the tropical and subtropical westem Atlantic: first revision. Nova Hedwigia Beiheft 116: I. Cramer, Berlin, Stuttgart: iii + $155 \mathrm{pp}$ 